\title{
단안 상사근마비환자에서 시행한 상사근접치기수술의 효과 The Clinical Course of Superior Oblique Tuck Surgery in Patients with Unilateral Superior Oblique Palsy
}

\author{
황현지· 강동현 · 김응수 · 백승희 \\ Hyun Ji Hwang, MD, Dong Hyun Kang, MD, Ungsoo Samuel Kim, MD, Seung-Hee Baek, MD, PhD \\ 건양대학교 의과대학 김안과병원 안과학교실 명곡안연구소 \\ Myung-Gok Eye Research Institute, Department of Ophthalmology, Kim's Eye Hospital, Konyang University College of Medicine, Seoul, Korea
}

\begin{abstract}
Purpose: To evaluate the effects of surgery depending on the follow-up duration after superior oblique tuck was performed as the first surgery in unilateral superior oblique palsy patients.

Methods: Sixteen patients who were followed-up for a minimum of 3 months were retrospectively evaluated. The vertical deviation, abnormal head posture, superior oblique underaction, and inferior oblique overaction were evaluated before and at 3,6 , and 12 months after the surgery and at the last follow-up. The angle between the center of the optic disc and fovea (disc-fovea angle) was measured using fundus photography to investigate changes in ocular torsion.

Results: The mean follow-up period was $24.9 \pm 21.9$ months and the mean tuck was $11.4 \pm 4.0 \mathrm{~mm}$. Vertical deviation $<7$ prism diopters in the primary position was observed in $53.9 \%$ of patients at 3 months postoperatively, $50.0 \%$ at 6 months, $83.3 \%$ at 12 months, and $62.5 \%$ at the last follow-up ( $p=0.55$ ). Head posture was improved in $66.7 \%$ of patients at 3 months, $71.4 \%$ at 6 months, $50 \%$ at 12 months, and $80 \%$ at the last follow-up after surgery $(p=0.73)$. Ocular torsion was decreased in $37.5 \%$ of patients at 3 months postoperatively, $66.7 \%$ at 6 months, $75 \%$ at 12 months, and $80.0 \%$ at the last follow-up $(p=0.11)$. Superior oblique underaction was improved in $100 \%, 77.8 \%, 60 \%$, and $75 \%$ of the patients and inferior oblique overaction was improved in $100 \%, 88.9 \%, 85.7 \%$, and $81.3 \%$ of the patients at postoperative month 3,6 , and 12 , and at the last follow-up, respectively.
\end{abstract}

Conclusions: Superior oblique tuck resulted in the maintenance of an improved condition of patients at 3,6 , and 12 months postoperatively, and there was no significant difference in motor measurements between the follow-up periods.

J Korean Ophthalmol Soc 2019;60(10):982-989

Keywords: Superior oblique palsy, Superior oblique tuck surgery

상사근마비는 단일 외안근마비 중 가장 흔한 질환으로 머리기울임, 수직사시, 복시, 얼굴비대칭이 있는 경우 수술 을 고려하게 되는데 수술 성공률은 $77-85 \%$ 로 보고되고 있

- Received: 2018. 11. 15.

- Revised: 2019. 3. 1.

- Accepted: 2019. 9. 24.

- Address reprint requests to Seung-Hee Baek, MD, PhD Kim's Eye Hospital, \#136 Yeongsin-ro, Yeongdeungpo-gu, Seoul 07301, Korea

Tel: 82-2-2639-7812, Fax: 82-2-2639-6359

E-mail: drslitlamp@kimeye.com

* Conflicts of Interest: The authors have no conflicts to disclose.
다. ${ }^{1,2}$ 상사근마비수술의 예후는 좋지만 재수술을 하게 되 는 경우가 드물지 않아서 $17 \%$ 에서 $40 \%$ 까지 ${ }^{1,3,4}$ 보고되며, Helveston et $\mathrm{al}^{5}$ 은 수술 후 증상이 호전되었거나 수직사시 와 머리기울임이 없어진 경우를 치료의 성공으로 정의하였 을 때 평균 1.26 회의 수술로 $92 \%$ 의 치료 성공률을 보고하 였다. 상사근마비환자의 임상증상이 다양하게 나타나므로 수술 방법은 다양하게 시행되고, 수술 방법의 결정이 항상 쉬운 것은 아니다. ${ }^{6}$ 수술 방법으로는 하사근약화술이 가장 많이 시행되는데 필요한 경우 수직근과 수평근수술을 함께 시행할 수 있으며, 상사근강화술인 상사근접치기수술은 상 
대적으로 드물게 시행된다. Knapp and Moore은 가장 큰 각의 상사시가 나타나는 양상에 따라 상사근마비를 분류하 고 상사근의 작용 방향에서 상사시가 가장 큰 제 2 형에서 기본적으로 단독 상사근접치기수술을 권유하였으나, 많은 술자가 상사근강화술보다는 하사근약화술을 선호하며 ${ }^{8}$ 상 사근접치기수술의 적응증은 아직까지 확실히 정립되지 않 았다고 할 수 있다. 상사근접치기수술은 상사근인대가 저 명하게 이완되어 있고 강조견인검사 결과 상사근인대가 이 완된 것이 확인된 경우에 시행하도록 권장되는데, ${ }^{5}$ 수술로 교정되는 수직편위량과 수술량의 상관관계가 일정하지 않 아서 수술 전 사시각으로 접침양을 미리 결정하기 어렵다 는 단점이 있다. ${ }^{1,5,9,10}$ 선천 상사근마비환자에서 상사시와 이상두위는 상사근강화술을 시행하는 가장 흔한 적응증이 며, ${ }^{5}$ 이외에도 후천 상사근마비환자에서 저명한 내전시 상 전장애나 회선복시가 있을 때, 양안 상사근마비에서도 시 행할 수 있다. ${ }^{8}$ 상사근접치기수술은 내전시 상전을 감소시 키는 효과가 저명하여 수술 직후 어느 정도의 브라운증후 군이 필연적으로 나타나는데, 심하지 않은 의인성 브라운 증후군은 시간이 경과함에 따라 호전되지만 ${ }^{11}$ 상사근접치 기수술의 효과 또한 시간이 지남에 따라 감소할 수 있다.

기존의 연구에서 수술 후 평균 경과 관찰기간은 3 개월에 서 19.8 개월 등 다양하게 보고되는데, ${ }^{3,12,13}$ 연구마다 수술의 성공 여부를 판단한 시점이 일정하지 않으며, 마지막 경과 관찰을 기준으로 수술 효과를 판단한 경우 시간의 흐름에 따른 수술 경과의 변화를 알기는 어렵다. 상사근마비환자 의 수술적 치료에 대한 국내 연구도 주로 하사근약화술에 집중되어서 상사근접치기수술의 치료 성적에 대한 국내 연 구가 부족한 상태이며, 기존의 한 국내 연구에서 경과 관찰 기간은 7.8 개월로 짧았고 다른 연구들과 마찬가지로 일정 하지 않은 특정 시점의 검사 결과를 바탕으로 수술 성적을 평가하였다. ${ }^{14}$ 이에 저자들은 본원에 내원하여 단안 상사근 마비를 진단받고 첫 수술로 상사근접치기수술을 시행한 환 자를 대상으로 경과 관찰시점에 따른 임상성적을 분석하여 시간의 경과에 따른 임상성적의 변화 및 상사근접치기수술 의 성공률에 대하여 알아보고자 하였다.

\section{대상과 방법}

저자들은 Institutional Review Board (IRB) 심의를 거쳐 연구 승인을 받았으며(승인 번호: 2018-03-002-002), 2010년 7월부터 2016년 4월까지 본원에서 단안 상사근마비 진단 후 첫 수술로 상사근접치기수술을 시행받은 환자들 중 술 후 3 개월 이상 경과 관찰이 가능하였던 총 16 명의 의무기 록을 후향적으로 분석하였다. 안와외상 또는 외안근수술의
병력이 있거나, 다른 안구운동장애가 동반된 경우, 수술 당 시 약시가 있었던 경우는 연구 대상에서 제외하였으며, 약 시는 스넬렌 시력표에서 두 눈의 시력이 두 줄 이상 차이가 나는 경우로 정의하였다. 사시검사상 마비안에 상사시가 나타나며, 마비안쪽으로 머리를 기울이거나 내전할 때 상 사시가 더욱 심해지는 경우 상사근마비를 진단하였고, 연 구에 포함된 16 명의 환자는 모두 두부 외상 혹은 수술, 뇌 혈관질환의 병력 없이 어려서부터 오래된 상사시가 있으면 서 머리기울임 및 얼굴돌림, 또는 얼굴 비대칭이 있는 경우 로 선천 상사근마비로 진단하였다.

상사근마비로 진단받은 환자 중 고개기울임이 저명하며 수술실에서 강조견인검사를 시행하였을 때 마비안에서 비 대칭적인 상사근인대의 이완이 확인된 경우에 마비안에 상 사근접치기수술을 시행하였다. 접치기 수술량은 Saunders ${ }^{8}$ 의 방법을 바탕으로 전적으로 수술 시 검사 소견에 따라 결 정하였는데, 수술실에서 확인한 상사근인대의 이완 정도에 따라 적당히 팽팽한 긴장도가 느껴질 정도로 상사근인대를 위로 당겨 올린 후 인대의 아래쪽을 겹쳐서 겸자로 잡고 6-0 vicryl로 봉합하여 임시 매듭을 만든 후, 견인검사를 통 해 당겨진 상사근인대가 적당히 팽팽한지 확인하고 필요한 경우 당긴 정도를 다시 조절하여 영구 봉합을 시행하였다. 제일눈위치에서 수직편위각이 20-25프리즘디옵터 이상인 경우에 하사근 또는 수직근수술을 병행하였다. 10 프리즘디 옵터 이상의 내사시가 있는 경우 및 20 프리즘디옵터 이상 의 외사시가 있는 경우 수평근수술을 추가하였다.

의무기록을 바탕으로 진단 및 수술 당시의 나이, 성별, 약시 유무, 수술량, 재수술 여부를 조사하였다. 모든 환자에 서 굴절검사를 시행하여 굴절이상을 교정하였고 수술 전과 후 가림검사와 가림안가림검사를 시행한 후 교대프리즘가 림법으로 $33 \mathrm{~cm}$ 와 $6 \mathrm{~m}$ 에서 원거리 및 근거리 사시각을 측 정하였으며, 이상두위를 기록하고 두눈동향운동검사를 시 행하여 상사근기능저하는 -1 to -4 , 하사근기능항진은 +1 to +4 의 4 단계로 표시하였다. 대상자의 양안 눈동자가 수평에 위치한 상태에서 촬영한 안저사진을 바탕으로 시신경유두 의 중심과 황반을 연결한 선과 수평선이 이루는 각도인 시 신경유두 중심과 망막중심오목이 이루는 각도(시신경유두망막중심오목각, disc-fovea angle, DFA)를 Adobe Photoshop Elements (Adobe Systems, San Jose, CA, USA)을 이용하 여 직접 측정하였고, ${ }^{15}$ 양안의 측정값을 더하여 수술 전과 후 안구회선 정도를 비교하였다. 외회선은 양의 정수값으 로, 내회선은 음의 정수값으로 정하여 양안의 측정값을 더 한 값이 감소한 경우는 외회선이 호전된 것으로 판단하였 다.

경과 관찰시점에 따른 수술 효과의 변화를 알아보기 위 
해 수술 후 $3,6,12$ 개월, 마지막 경과 관찰 시 제일눈위치 와 머리기울임 시 수직사시각, 양안의 시신경유두-망막중 심오목각의 합의 평균을 각 시점별로 비교하였다. 시신경 유두-망막중심오목각의 합이 평균이 $0.5^{\circ}$ 이상 차이가 있는 경우 호전 또는 악화로 판단하였으며, 상사근기능저하 및 하사근기능항진의 4 단계 중 1 단계 이상 호전된 경우 사근 기능 이상이 호전된 것으로 판단하였다. 수술 후 제일눈위 치의 수직사시각이 7프리즘디옵터 이하, 안구회선, 머리기 울임, 상사근기능저하 및 하사근기능항진이 수술 후 호전 을 보인 환자의 비율을 구하고 각 시점별로 비교하였다.

수술 성공은 제일눈위치에서 수직사시각이 7프리즘디옵 터 이하이면서 머리기울임이 호전되거나 없어진 경우로 정 의하였고, 수술 후 $3,6,12$ 개월, 마지막 경과 관찰 시 각 시 점별로 수술 성공률을 비교하였다. 재수술을 시행한 경우 는 첫 번째 수술이 실패한 것으로 판단하였고, 따라서 재수 술 시행 직전의 경과 관찰을 마지막 경과 관찰로 간주하여 첫 번째 수술의 경과만을 주 분석에 포함하였다.

각각의 측정 변수에서 수술 후 $3,6,12$ 개월, 마지막 경과 관찰 시의 수술 성공률을 카이제곱검정을 시행하여 시점별 로 비교하였으며, 변수들 사이의 연관관계에 대한 분석은 Spearman 상관분석을 이용하였다. 통계분석에는 SPSS 프 로그램(SPSS ver. 12.0 for Windows, SPSS Inc., Chicago, $\mathrm{IL}, \mathrm{USA}$ )을 이용하였고 0.05 미만의 $p$-value를 통계학적으 로 유의한 값으로 정의하였다.

\section{결 과}

연구에는 총 16 명(남자 8 명, 여자 8 명)이 포함되었는데 모든 환자에서 단안의 선천성 마비로 생각되었다. 환자들 은 복시가 없이 발생 시기를 정확히 알 수 없는 오래된 상 사시가 있고, 어릴 때 사진에서 고개기울임을 확인하였으 며 제일눈위치에서 평균 20.4프리즘디옵터의 상사시를 보 였다. 수술 후 평균 경과 관찰기간은 $24.9 \pm 21.9$ 개월(5-66개 월)이었으며, 수술 시 평균나이는 $13.4 \pm 12.4$ 세(3-50세)였 다. 상사근접치기 수술의 수술량을 접쳐진 부분의 총 길이 를 측정한 값으로 하였을 때 평균 수술량(접침양)은 $11.4 \pm$ $4.0 \mathrm{~mm}(6-20 \mathrm{~mm})$ 였다. 총 16 명의 단안 상사근마비환자 중 외사시가 같이 있었던 경우가 2명, 내사시가 같이 있었 던 경우가 2명이었고 수술 전 검사에서 상사근기능저하가 기록된 경우가 11 안(-3 to $-4,2$ 명; -1 to $-2,9$ 명)이었고 하 사근기능항진이 확인된 경우는 14 안 $(+3$ to $+4,8$ 명; +1 to $+2,6$ 명)이었다. 8 명의 환자에서 단안의 상사근접치기수술 만을 시행하였고, 3 명의 환자에서 수평근수술, 2 명의 환자 에서 동측의 하사근약화술, 2 명의 환자에서 반대안의 하직
근후전술을 동시에 시행하였다. 한 명의 환자에서는 마비 안의 상직근 구축이 확인되어 상직근후전술을 동시에 시행 하였다. 재수술은 5 명에서 시행하였는데 첫 수술로부터 평 균 $33.0 \pm 25.3$ 개월(5-67개월)후에 시행하였다(Table 1).

제일눈위치와 마비안쪽으로 머리기울임 시 수직사시각 의 평균값과 시싱경유두-망막중심오목각의 평균은 수술 후 감소하여 $3,6,12$ 개월, 마지막 경과 관찰시점에서 수술 전 보다 감소한 상태로 유지되었다. 제일눈위치 수직사시각의 평균은 수술 후 3 개월과 수술 후 12 개월째에 비슷한 값을 보였으며, 머리기울임 시 수직사시각과 시신경유두-망막중 심오목값의 평균은 수술 후 3 개월과 마지막 경과 관찰 시 비슷한 값을 보였다(Table 2). 술 후 제일눈위치에서 수직 사시각이 7프리즘디옵터 이하로 유지된 경우는 술 후 3 개 월, 6 개월, 12 개월, 마지막 경과 관찰 시 각각 $53.8 \%, 50 \%$, $83.3 \%, 62.5 \%$ 로 통계적으로 유의한 차이를 보이지 않았다. 이상두위가 호전된 환자의 비율은 마지막 경과 관찰 시 $80 \%$ 로 가장 높게 나타났으며, 안구회선의 정도가 호전된 환자의 비율은 점차 증가하여 마지막 경과 관찰 시 $80 \%$ 로

Table 1. Baseline characteristics of patients with unilateral superior oblique palsy

\begin{tabular}{lc}
\hline Characteristic & Value \\
\hline Age at the time of surgery (years) & $13.44 \pm 12.41$ \\
Median (range) & $9.5(3-50)$ \\
Age at time of diagnosis (years) & $13.81 \pm 13.17$ \\
Sex (male:female) & $8(50): 8(50)$ \\
Affected side of eye & \\
Right:left & $8(50): 8(50)$ \\
Preoperative baseline spherical equivalent & $-1.4:-1.6$ \\
OD:OS (diopters) & \\
Time from diagnosis to surgery (months) & $9.40 \pm 13.18$ \\
Follow-up period after surgery (months) & $24.94 \pm 21.93$ \\
Preoperative maximum vertical deviation in & $20.41 \pm 9.66$ \\
primary position (PD) & \\
Amount of tucking (mm) & $11.38 \pm 4.08$ \\
Preoperative diagnosis & \\
SO palsy only & $12(75)$ \\
SO palsy with exotropia & $2(12.5)$ \\
SO palsy with esotropia & $2(12.5)$ \\
Type of surgery & \\
SO tuck only & $8(50)$ \\
SO tuck with horizontal muscle surgery & $3(18.75)$ \\
SO tuck and IO weakening & $2(12.5)$ \\
SO tuck and contralateral IR recession & $2(12.5)$ \\
SO tuck and SR recession & $1(6.25)$ \\
\hline All cases are &
\end{tabular}

All cases are presumably congenital $(n=16)$. Values are presented as mean \pm standard deviation or number $(\%)$ unless otherwise indicated.

$\mathrm{OD}=$ oculus dexter; $\mathrm{OS}=$ oculus sinister; $\mathrm{PD}=$ prism diopters; $\mathrm{SO}=$ superior oblique; $\mathrm{IO}=$ inferior oblique; $\mathrm{IR}=$ inferior rectus; $\mathrm{SR}=$ superior rectus. 
가장 높았고, 반면 상사근기능저하와 하사근기능항진이 호 전된 환자의 비율은 수술 후 3 개월에 가장 높고 이후에는 낮았으나 각 시점별 변화는 통계적으로 유의한 차이는 아 니었다(Table 3). 상사근접치기수술의 성공률은 수술 후 3 개월에 $46.2 \%, 6$ 개월에 $50 \%, 12$ 개월에 $66.7 \%$ 로 성공률이 점차 높아졌으나 경과 관찰기간에 따라 유의한 차이는 없 었으며, 마지막 경과 관찰시점 기준으로 $56.3 \%$ 였다 $(p=0.85$, Fig. 1). 상사근접치기수술만 시행한 경우와 수직근 혹은 하 사근수술을 추가한 경우를 비교해보았을 때, 수술 전 제일 눈위치의 수직편위각은 상사근접치기수술을 단독 시행한 군에서 평균 15.1 프리즘디옵터였으며 수직근 혹은 하사근 수술을 병행한 군에서는 평균 30.5 프리즘디옵터로 더 큰 술 전 사시각을 보였다 $(p=0.006)$. 수술 후 성공률은 수술 후 6 개월에 상사근접치기수술 단독은 $67 \%$, 수직근 또는 하 사근수술을 병행한 경우 $50 \%$ 였고 $(p=0.60)$, 마지막 경과 관 찰 시 각각 $75 \%, 40 \%$ 였으나 $(p=0.21)$ 수술 종류에 따른 차 이는 통계적인 유의성에 이르지 못하였다.

연구에 포함된 16 명 중 5 명에서 첫 번째 상사근접치기수 술 이후 1 회 이상의 재수술을 시행하였고, 연구 대상자인 16 명 이외에 상사근접치기수술 후 3 개월 이상 경과 관찰하 였던 경우 중 첫 수술 후 심한 의인성 브라운증후군으로 술 후 2주째 접친 근육을 풀었던 경우가 1예 있었다. 이 17 명 에서 첫 상사근접치기수술 후 재수술을 포함한 수술 성공
률의 경과를 보면, 수술 후 $3,6,12$ 개월 경과 관찰 시 성공 률이 점차 증가하여 12 개월에 $75 \%$ 를 보였으며 시간 경과

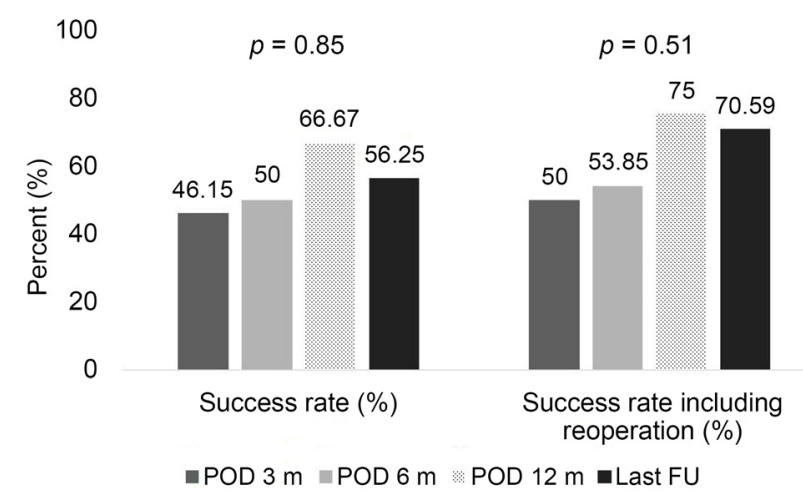

Figure 1. Change of success rates after superior oblique tuck surgery for unilateral superior oblique palsy with or without considering reoperations. Success of the surgery is defined as follows: 1) Vertical deviation in primary position $\leq 7$ prism diopters and 2) Improvement of abnormal head posture and 3) no reoperation. Success including reoperation is defined as 1) and 2) only. There was no significant difference in success rates among the follow-up periods including reoperations or not (chi-square test, $p>0.05$ ). 'POD 3 m' means 3 months after surgery, 'POD $6 \mathrm{~m}$ ' means 6 months after surgery. 'POD 12 m' means 12 months after surgery. POD = postoperative; $\mathrm{FU}$ = follow-up.

Table 2. Vertical deviations and foveal torsions during the follow-up of superior oblique tuck surgery in unilateral SOP patients

\begin{tabular}{lccccc}
\hline Variable & $\begin{array}{c}\text { Pre-operative } \\
\text { measurements }(\mathrm{n}=16)\end{array}$ & $\begin{array}{c}\text { POD 3 } \mathrm{m} \\
(\mathrm{n}=13)\end{array}$ & $\begin{array}{c}\text { POD 6 m } \\
(\mathrm{n}=12)\end{array}$ & $\begin{array}{c}\text { POD 12 m } \\
(\mathrm{n}=6)\end{array}$ & $\begin{array}{c}\text { Last follow-up } \\
(\mathrm{n}=16)\end{array}$ \\
\hline $\begin{array}{l}\text { Vertical deviation } \\
\text { in the primary position (PD) }\end{array}$ & $20.41 \pm 9.66$ & $4.31 \pm 6.45$ & $6.42 \pm 6.87$ & $3.17 \pm 6.82$ & $7.59 \pm 10.71$ \\
$\begin{array}{l}\text { Vertical deviation when head tilted to } \\
\text { the side of the hypertropic eye (PD) }\end{array}$ & $22.54 \pm 12.25$ & $10.75 \pm 10.63$ & $4.00 \pm 9.19$ & $7.00 \pm 8.89$ & $9.78 \pm 10.89$ \\
Disc-fovea angle (degrees) & $21.35 \pm 7.28$ & $16.86 \pm 7.05$ & $14.69 \pm 9.07$ & $19.2 \pm 9.05$ & $16.01 \pm 7.35$ \\
\hline
\end{tabular}

Values are presented as mean \pm standard deviation.

$\mathrm{SOP}=$ superior oblique palsy; $\mathrm{POD}=$ postoperative $; \mathrm{m}=$ months; $\mathrm{PD}=$ prism diopters.

Table 3. Surgical results of each parameters during the follow-up after superior oblique tuck surgery in unilateral SOP patients

\begin{tabular}{|c|c|c|c|c|c|}
\hline Variable & $\begin{array}{l}\text { POD } 3 \mathrm{~m} \\
(\mathrm{n}=13)\end{array}$ & $\begin{array}{l}\text { POD } 6 \mathrm{~m} \\
(\mathrm{n}=12)\end{array}$ & $\begin{array}{c}\text { POD } 12 \mathrm{~m} \\
(\mathrm{n}=6)\end{array}$ & $\begin{array}{l}\text { Last follow-up } \\
\quad(\mathrm{n}=16)\end{array}$ & $p$-value ${ }^{*}$ \\
\hline Vertical deviation in primary position (PD) $\leq 7 \mathrm{PD}$ & 53.85 & 50 & 83.33 & 62.5 & 0.55 \\
\hline Improvement of abnormal head posture & 66.66 & 71.43 & 50 & 80 & 0.73 \\
\hline Reduction of disc-fovea angle & 37.5 & 66.67 & 75 & 80 & 0.11 \\
\hline Improvement of SOUA & 100 & 77.78 & 60 & 75 & 0.34 \\
\hline Improvement of IOOA & 100 & 88.89 & 85.71 & 81.25 & 0.55 \\
\hline
\end{tabular}

Values are presented as $\%$.

$\mathrm{SOP}=$ superior oblique palsy; $\mathrm{POD}=$ postoperative; $\mathrm{m}=$ months $; \mathrm{PD}=$ prism diopters; $\mathrm{SOUA}=$ superior oblique underaction; $\mathrm{IOOA}=$ inferior oblique overaction.

${ }^{*}$ Chi-square test. 
에 따른 유의한 차이는 없었고, 마지막 경과 관찰시점 기준 으로 $70.6 \%$ 의 성공률을 보였다(Fig. 1). 첫 수술 후 의인성 브라운증후군을 보인 1 명을 제외한 5 명은 첫 번째 수술 후 평균 $33 \pm 25.3$ 개월(5-67개월)에 제일눈위치에서 평균 17.6 \pm 14 .1프리즘디옵터 수직사시로 두 번째 수술을 시행하였 으며, 4 명은 1 회의 재수술을 받았고 1 명은 첫 수술 후 재수 술을 3 차례 더 시행하였다. 재수술의 적응증은 제일눈위치 에서 상사시가 지속되거나 머리기울임이 수술 전과 차이 없이 지속되는 경우에 시행하였는데, 4 명에서 재수술을 시 행하기 전 상사시가 첫 수술 전과 비슷한 수준으로 측정되 었고, 1 명에서는 첫 수술 후 상사시는 2 프리즘디옵터였으 나 머리기울임이 수술 전과 비교하여 호전을 보이지 않아 재수술을 시행하였다. 상직근이 팽팽했던 환자에서는 상직 근후전술을, 상사근접치기수술 후 호전되지 않은 저명한 하사근기능항진을 보인 환자에서는 하사근후전술을 시행 하였으며, 2 명에서 하사근절제술을 시행하였다. 3 차례의 재수술을 시행한 1 명에서 첫 재수술 시 마비안 반대쪽의 하직근후전술을 시행하였고 이후 과교정으로 마비안 반대 쪽의 하사근후전술 및 하직근전진술을 시행하였으며, 이후 잔여 외사시에 대한 수평근수술을 시행하였다. 모든 경우 에서 수술 직후 내전시 상전장애가 발생하였으나 제일눈위 치에서 하사시를 보인 경우는 16 안 중 1 안이었고 수술 후 6 일째 제일눈위치에서 하사시가 소실되어 마지막 경과 관 찰시점인 술 후 21 개월까지 수술 성공의 기준을 만족하였 다. 재수술환자를 포함하는 과정에서 추가된 1 명의 환자는 의인성 브라운증후군으로 수술 후 2 주째 재수술을 시행한 환자로 우안의 상사근접치기수술 후 1 일째 제일눈위치에서 10 프리즘디옵터의 우안 하사시를 보였으며 우안 상전장애 -4 로 호전이 느리고 계속 복시를 호소하여 수술 후 14 일째 상사근후전술을 시행하였고, 이후 마지막 경과 관찰 시 제 일눈위치 수직편위는 3 프리즘디옵터였으나 고개기울임은 지속되어 수술 성공의 기준을 만족하지는 못하였다.

\section{고 찰}

저자들은 단안 상사근마비환자에서 첫 수술로 단안의 상 사근접치기수술을 시행한 후 경과 관찰 시 수술 효과와 성 공률의 변화 양상을 알아보고자 하였다. 단안 상사근마비 는 삼 단계 검사와 과거력을 바탕으로 진단하였는데, 연구 에 포함된 환자들은 복시가 없이 발생 시기를 정확히 알 수 없는 오래된 상사시가 있고, 어릴 때 사진에서 고개기울임 을 확인하였으며 제일눈위치에서 큰 각도의 상사시를 보여 임상적으로 단안 선천상사근마비의 진단에 해당하는 경우 였다. 감별진단으로 해리수직편위, 수직근수술로 인해 근력
이 약해진 경우, 스큐편위, 눈중증근무력증 등을 고려할 수 있으나 수술력이 있는 환자는 제외하였으며 해리수직편위, 스큐편위 및 눈중증근무력증을 의심할 만한 소견을 보인 환자는 없었다. 양안 상사근마비는 대부분 두부외상으로 인한 후천성마비로 비대칭적인 경우가 흔해서 단안의 상사 근마비로 오인될 수 있는데, 이러한 병력이 있는 환자들에 서 좌측주시 시 우안 상사시 및 우측 주시 시 좌안 상사시 를 보이거나 양측 Bielschowsky head tilt test가 양성일 때 진단적이라 할 수 있다. ${ }^{16}$ 이 연구에 포함된 환자는 모두 특 별한 외상, 수술 등의 병력이 없었고 양측 Bielschwsky head tilt test 양성이거나 양안 상사근마비를 의심할 만한 V형 사시 혹은 턱내림 두위를 보인 환자는 없었다. 저자들은 하 사근기능항진의 정도와 유무보다는 상사근기능저하가 있 고 고개기울임이 저명한 선천성 단안 상사근마비환자에서 수술 시 시행한 강조견인검사 결과에 따라 양측의 상사근 인대를 비교하여 마비안에서 상사근인대 이완이 저명하게 확인된 경우 단안 상사근접치기수술을 시행하였다.

총 16 명의 환자를 대상으로 하였는데, 이전 국내의 상사 근접치기수술의 연구 대상자는 13-22명으로 연구 대상자 규모가 크지 않은 것은 국내에서도 하사근약화술에 비해 상사근접치기수술을 많이 시행하지 않는 경향이 반영된 결 과이다. 과거 연구에서 수술 후 평균 경과 관찰기간은 3 개 월에서 19.8 개월까지 $3,5,12,13$ 보고되고 있으며, 국내 연구에 서 수술 후 평균 관찰기간은 7.8 개월로 ${ }^{14}$ 저자들의 연구는 국내 환자를 대상으로 평균 경과 관찰기간이 수술 후 24.3 개 월로 이전 연구보다 길었고, 수술 후 다양한 시점의 결과가 혼재되어 있는 기존 국내외 연구들과는 달리 모든 환자에 서 일정한 특정 시점에서의 수술 성적을 평가하여 시간 경 과에 따른 수술 효과의 변화를 알아보았다.

상사근접치기수술의 효과는 제일눈위치와 마비근의 작 용 방향에서 상사시와 외회선의 감소로 나타나고, 특히 선 천성 상사근마비환자에서 머리기울임의 교정에 효과가 있 다는 보고들이 있다. $5,8,11,14$ 이번 연구에서 수직사시각과 안 구회선의 정도는 수술 후 호전된 상태를 보여 수술 후 3, 6,12 개월까지 유지되었으며 제일눈위치에서 평균 수직사 시각은 수술 전 $20.4 \pm 9.6$ 프리즘디옵터 상사시에서 마지막 경과 관찰 시 $7.6 \pm 10.7$ 프리즘디옵터 상사시로 평균 12.9 프 리즘디옵터 감소하였고 수술 후 12 개월까지는 경과 관찰시 점에 따른 유의한 차이를 보이지 않았다. 기존 연구에서는 제일눈위치에서 수술 후 평균 6.7-8.8프리즘디옵터의 상사 시를 보여 ${ }^{12,14}$ 마지막 경과 관찰시점에서의 수직사시각과 비슷한 값을 보였고, 수술 후 3 개월 및 12 개월 후의 수직편 위각은 그보다 더 작은 평균값을 보였다. 객관적 회선 변화 를 보기 위해 측정한 양안의 시신경유두-망막중심오목각의 
합은 수술 전 평균 $21.4 \pm 7.3^{\circ}$ 에서 마지막 경과 관찰 시 $16.0 \pm 7.4^{\circ}$ 로 평균 $5.4^{\circ}$ 감소하여 외회선은 수술 후 감소한 것을 알 수 있으며, 상사근마비환자를 대상으로 하사근약 화술을 시행한 이전 연구들은 평균 $5.1-8.7^{\circ}$ 의 외회선 감소 를 보고하여 저자들의 연구와 비슷한 결과를 보였다. ${ }^{15,17,18}$

제일눈위치에서 수직사시각이 7프리즘디옵터 이하로 유지된 경우와 머리기울임이 호전된 경우는 마지막 경과 관찰 시 각각 $62.5 \%, 80 \%$ 였으며 경과 관찰시점에 따른 유 의한 차이는 없었으나, 수직사시각이 7 프리즘디옵터 이하 로 유지된 환자는 수술 후 12 개월에 $83.3 \%$ 로 가장 높은 비 율을 보였다. 머리기울임의 경우 마지막 경과 관찰시점을 기준으로 했을 때 $80 \%$ 의 환자에서 수술 전보다 호전을 보 였다. 국내 환자를 대상으로 한 기존의 연구는 단안의 상사 근마비에 대한 치료로 상사근접치기수술을 단독으로 시행 한 환자 13 명 중 잔류 수직사시가 7프리즘디옵터 이하인 경우가 $46.2 \%$ 였고 술 전 이상두위가 있었던 10 명 중 $50 \%$ 인 5 명에서 $5^{\circ}$ 이상 호전되었다는 보고가 있었는데 ${ }^{14}$ 이번 연구에서는 더 높은 비율의 환자에서 이상두위의 호전을 보였으며, 상사근접치기수술 이외 하사근이나 다른 수직근 수술을 함께 시행한 다른 연구에서는 수술 후 $89 \%$ 에서 이 상두위가 없어졌다고 보고하여 저자들의 12 개월째의 연구 와 비슷한 결과를 확인할 수 있었다.

경과 관찰기간이 길어짐에 따라 상사근기능저하와 하사 근기능항진의 호전을 보인 환자의 비율은 수술 후 3 개월에 $100 \%$ 이고 이후 경과 관찰 시 감소한 값을 보였으며, 마지 막 경과 관찰시점을 기준으로 했을 때 각각 $76.5 \%, 81.3 \%$ 에서 수술 전보다 호전되었다. 시신경유두-망막중심오목각 (disc-fovea angle)의 호전을 보인 환자의 비율은 경과 관찰 기간이 길어질수록 증가하여 수술 후 12 개월에 가장 높았 으며, 마지막 경과 관찰시점 기준으로 $80 \%$ 의 환자에서 수 술 전보다 호전된 상태를 보여 안구회선의 정도는 경과 관 찰기간이 긴 경우에 호전을 보인 환자의 비율이 더 높았으 나 경과 관찰시점에 따른 유의한 차이는 없었다.

기존 연구에 의하면 상사근접치기수술 단독으로 시행했 을 경우 $66-71 \%$ 의 성공률이 보고되었는데, ${ }^{3,9}$ 수술 성공의 정의는 연구마다 다양하다. 저자들은 수술의 성공은 상사 근접치기수술의 성공을 제일눈위치에서 수직사시각이 7프 리즘디옵터 이하이면서 이상두위의 호전을 보인 경우로 정 의하였고 이전 국내 연구에 저자들의 연구와 동일한 기준 을 적용하면 13 명 중 5 명인 $38.5 \%$ 에서 두 가지 조건을 모 두 만족하였다. ${ }^{14}$ 상사근접치기수술을 시행한 단안 상사근 마비환자 15 명을 대상으로 이상두위의 호전과 함께 원거리 주시 시 제일눈위치에서 복시가 사라지거나 하측 주시 시 복시가 사라진 경우를 모두 포함하여 수술 성적이 좋다고
판단한 Morris et $\mathrm{al}^{9}$ 의 연구에서는 $66.6 \%$ 에서 좋은 수술 성적을 보였다고 보고하였다. 반면 Durnian and $\mathrm{Marsh}^{3}$ 는 수술 후 복시가 사라진 경우를 수술의 성공으로 정의하였 고, 75 명의 성인 상사근마비환자를 대상으로 첫 수술로 상 사근접치기수술을 시행했을 때 재수술을 포함하지 않은 수 술 성공률을 $71 \%$ 로 보고하였다. 하지만 앞선 연구들은 일 정하지 않은 특정 시점에서의 결과를 바탕으로 수술의 효 과를 평가한 것으로 시간의 경과에 따른 효과의 변화를 연 구하지는 않았으며, 평가한 시점이 일치하지 않는 경우가 대다수였다. 상사근접치기수술 단독 시행 후, 수술 후 3 개 월에 일괄적으로 수술 후 경과를 평가하여 제일눈위치에서 수직사시각이 평균 4프리즘디옵터가 감소하였다는 연구가 있었으나 ${ }^{4}$ 수술 효과를 판단하기에 3 개월은 비교적 짧은 기간이라 할 수 있으며, 시간 경과에 따른 변화가 아닌 한 시점의 단편적인 결과를 보여주고 있다는 점에서 제한적이 라 할 수 있다. 저자들의 연구에서 수술 후 12 개월에 수술 성공률은 $66.7 \%$ 였으며, 마지막 경과 관찰시점의 성공률은 $56.3 \%$ 로 이전 연구와 큰 차이를 보이지 않았다. 또한 첫 수 술 후 심한 의인성 브라운증후군으로 술 후 2 주째 접친 근 육을 풀었던 1예 및 재수술 이후의 경과 관찰기간을 모두 포함하면 17 명에서 총 25 회의 수술을 시행하여 1 명당 평균 1.47 회의 수술로 마지막 경과 관찰시점에 $70.59 \%$ 의 수술 성공률을 보였다(Fig. 1).

평균 접침양은 $11.4 \mathrm{~mm}$ 였으며, 제일눈위치에서 수직편 위량은 수술 전 평균 20.4프리즘디옵터, 수술 후 마지막 경 과 관찰 시 평균 7.6 프리즘디옵터였다. 앞서 발표된 여러 연구에서 밝힌 바와 같이 수술 후 교정된 수직편위량과 접 침양 사이에 의미있는 상관관계가 없고 접침양은 수술 전 수직편위의 정도와 수술 중 강제당김검사 시 상사근의 이 완된 정도와 관련이 있다는 보고가 있을 뿐이어서 수술 전 사시각으로 적절한 수술량을 결정할 수 없고 수술 후 결과 를 예측하는 것이 어렵다. ${ }^{9}$ 상사근접치기수술의 수술량 결 정은 전신마취 후 시행하는 수술 중 검사에 의존하게 되며 대체로 접침양과 무관하게 수술 전 상사시가 클 때 교정되 는 수직사시각이 큰 경향이 있는 것으로 알려져 있으며, 이 번 연구에서도 이전의 연구들과 마찬가지로 접침양과 최종 수직편위량 사이에 의미있는 상관관계는 없었고(Spearman's $\mathrm{rho}=0.361, p=0.17$ ), 접침양과 교정된 수직편위량 사이에도 역시 의미있는 상관관계는 없었다(Spearman's $\mathrm{rho}=0.127$, $p=0.64)$.

상사근접치기수술은 불완전한 상사근마비로서 하사근기 능항진 없이 상사근기능저하가 저명할 때 시행하는 술자들 이 많다. ${ }^{11}$ 하지만 이번 연구에서는 상사근기능저하가 수술 전 검사에서 확인된 경우가 11 안이었고 수술 전 하사근기 
능항진이 확인된 경우도 14 안 포함되어 수술 전 상사근기 능저하가 필수적인 적응증은 아니라고 생각되며, 상사근접 치기수술 후 의인성 브라운증후군이 생기면 하사근기능항 진은 호전되는 효과가 있어서 $80 \%$ 이상의 환자에서 하사 근기능항진이 호전된 상태로 12 개월까지 유지되었다. 상사 근기능저하와 관련하여 상사근인대가 느슨한 경우 가벼운 하사근기능항진이 있어도 상사근접치기수술이 효과적일 수 있다고 하였으나 ${ }^{10}$ 전신마취 후 수술 직전 시행한 강조 견인검사 결과 16 안 중 16 안에서 마비안의 상사근인대의 이완이 있었다. 또한 그중 2명에서는 수술하지 않은 쪽의 인대도 느슨하였으나 수술한 반대쪽과의 차이가 저명하였 으며, 한 눈 상사근접치기수술 후 마지막 경과 관찰시점까 지 반대안의 상사시는 나타나지 않았다. 상사근인대의 이 완이 심하지 않고 양안의 차이도 뚜렷하지 않았던 1 안에서 는 수술 소견상 마비안의 상사근 크기가 비교적 작았던 것 을 확인하였다. 따라서 단순히 상사근인대의 느슨한 정도 보다는 반대안과 비교하였을 때 마비안에서 느슨한 정도가 심한 경우, 혹은 근육의 크기가 마비안에서 더 작은 소견이 수술의 적응증을 판단하는 데에 도움이 될 것으로 생각된다.

상사근접치기수술 후 의인성 브라운증후군은 4.5-17\%로 다양하게 보고되며 ${ }^{1,9}$ 이 연구의 주 분석에 포함된 16 명 모 두에서 수술 직후 내전시 상전제한이 나타났으나, 1 명에서 만 수술 후 1 일째 제일눈위치에서 하사시를 보인 의인성 브라운증후군을 경험하였으며 수술 후 6 일째 하사시가 사 라지면서 수술 성공으로 분류되었다. 저자들은 재수술환자 를 포함한 성공률을 분석하는 과정에서 추가된 1 명의 환자 에서 심한 의인성 브라운증후군을 경험하여 수술 후 14 일 째에 접친 근육을 풀어주기 위한 재수술을 시행하였다. 이 연구에서 술 후 심한 브라운증후군이 적은 것은 상사근접 치기수술 시 견인검사를 시행하여 상사근인대의 긴장도를 확인한 후 접침양을 조정하였기 때문으로 생각한다.

저자들은 16 명 중 5 명 $(31.3 \%)$ 의 환자에서 상사근접치기 수술과 함께 하사근 혹은 수직근수술을 병행하였으며 환자 의 상태에 따라 적절한 수술을 함께 시행하는 것이 수술의 효과를 높일 수 있는 것으로 생각된다. 두 개의 근육을 동 시에 수술하는 적응증에 대해서는 다양한 보고가 있는데 Helveston과 Kushner는 제일눈위치에서 15프리즘디옵터 이 상의 상사시가 있는 경우, ${ }^{5}$ von Noorden은 마비안쪽으로 주시시 25 프리즘디옵터 이상, ${ }^{12}$ Saunders ${ }^{19}$ 는 마비안쪽으로 주시시 30 프리즘디옵터 이상 상사시가 있는 경우 2 개 근육 을 동시에 수술할 것을 제안하였고, 이번 연구에서 2 근육을 수술한 5 예는 수술 전 제일눈위치에서 20 프리즘디옵터 상 사시를 보인 1 안을 제외하고 제일눈위치에서 30 프리즘디 옵터 이상의 상사시를 보인 경우였다. 제일눈위치에서 20 프
리즘디옵터의 상사시를 보였으나 2 개 근육을 수술한 1 예 에서 상사근접치기와 함께 하사근후전술을 시행하였는데, 수술 전 검사상 하사근기능항진 +2 , 상사근기능저하 -3 , 내 전시 수직편위가 제일눈위치에서보다 10 프리즘디옵터 이상 증가하였으며 수술 소견상 하사근의 두께가 매우 두꺼웠다.

연구의 제한점은 후향적 의무기록 연구로 환자가 내원할 때마다 모든 검사를 빠짐없이 시행하지 않아서 상사근기능 저하 혹은 하사근기능항진에 대한 기록이 누락된 경우가 있었고, 연구에서 정한 경과 관찰시점에 환자가 내원하지 않아서 결과 분석에 누락되는 경우가 있었다. 시신경 유두망막중심오목각을 측정하여 안구회선의 변화를 평가하는 과정에서 $0.5^{\circ}$ 의 임의적인 기준을 사용하였는데 검사자의 측정 오차가 $0.5^{\circ}$ 보다 큰 경우도 있을 수 있어 안구 회선의 호전 및 악화를 판단하는 데에 오차가 있을 수 있다. 모든 환자에서 마지막 경과 관찰기간이 상이하여 경과 관찰기간 은 평균 24.9 개월이었으나 표준편차가 커서 6 개월 이후 각 시점에서 증례 수가 많지 않았고, 수술 후 12 개월 시점에서 의 결과를 바탕으로 수술의 장기적인 효과를 판단하는 데 는 부족함이 따른다. 또한 상사근접치기수술만을 단독으로 시행한 환자는 8 명에 불과하여 상사근접치기수술 단독의 효과를 분석하기에는 제한이 있다. 따라서 다수의 환자를 바탕으로 보다 긴 경과 관찰기간을 갖는 추가적인 연구가 필요할 것으로 생각한다.

이와 같은 제한점에도 불구하고 저자들의 연구는 국내 환자를 대상으로 이전 연구보다 장기간 경과 관찰한 상사 근접치기수술의 수술 성적에 대한 연구이며, 일정한 경과 관찰시기에 따른 치료 효과의 변화를 연구하였다는 점에서 의미가 있다. 결론적으로 상사근접치기수술의 효과는 수술 후 평균 경과 관찰기간인 24.9 개월동안 수술의 효과가 경 과 관찰시점에 따른 유의한 변화없이 호전된 상태로 유지 되었고, 상사근접치기수술 후 마지막 경과 관찰시점에서 제일눈위치에서 수직편위가 7프리즘디옵터 이하인 경우가 $62.5 \%$ 였으며, $80 \%$ 에서 이상두위의 호전을 보여 마지막 경 과 관찰시점의 성공률은 $56.3 \%$ 로 이전 연구와 큰 차이를 보이지 않았다.

\section{REFERENCES}

1) Helveston EM, Ellis FD. Superior oblique tuck for superior oblique palsy. Aust J Ophthalmol 1983;11:215-20.

2) Knapp P. Classification and treatment of superior oblique palsy. Am Orthopt J 1974;24:18-22.

3) Durnian JM, Marsh IB. Superior oblique tuck: its success as a single muscle treatment for selected cases of superior oblique palsy. Strabismus 2011;19:133-7.

4) Nejad M, Thacker N, Velez FG, et al. Surgical results of patients 
with unilateral superior oblique palsy presenting with large hypertropias. J Pediatr Ophthalmol Strabismus 2013;50:44-52.

5) Helveston EM, Mora JS, Lipsky SN, et al. Surgical treatment of superior oblique palsy. Trans Am Ophthalmol Soc 1996;94:315-28.

6) Toosi SH, von Noorden GK. Effect of isolated inferior oblique muscle myectomy in the management of superior oblique muscle palsy. Am J Ophthalmol 1979;88:602-8.

7) Knapp P, Moore S. Diagnosis and surgical options in superior oblique surgery. Int Ophthalmol Clin 1976;16:137-49.

8) Saunders RA. When and how to strengthen the superior oblique muscle. J AAPOS 2009;13:430-7.

9) Morris RJ, Scott WE, Keech RV. Superior oblique tuck surgery in the management of superior oblique palsies. J Pediatr Ophthalmol Strabismus 1992;29:337-46; discussion 347-8.

10) Bhola R, Velez FG, Rosenbaum AL. Isolated superior oblique tucking: an effective procedure for superior oblique palsy with profound superior oblique underaction. J AAPOS 2005;9:243-9.

11) Rosenbaum AL, Santiago AP. Clinical strabismus management: principles and surgical management. Superior oblique procedures. Philadelphia: WB Saunders Company, 1999; chap. 35.

12) von Noorden GK, Murray E, Wong SY. Superior oblique paralysis. A review of 270 cases. Arch Ophthalmol 1986;104:1771-6.
13) Gräf M, Lorenz B, Eckstein A, Esser J. Superior oblique tucking with versus without additional inferior oblique recession for acquired trochlear nerve palsy. Graefes Arch Clin Exp Ophthalmol 2010;248:223-9.

14) Seo SW, Moon HS, Lee JH. Effect of superior oblique tuck surgery in the patients with unilateral superior oblique palsy. J Korean Ophthalmol Soc 2000;41:1968-73.

15) Ducca BL, Souza-Dias CR, Lui AC, Goldchmit M. Measurement of ocular torsion variation following superior oblique tenectomy. Arq Bras Oftalmol 2014;77:364-7.

16) von Noorden GK, Campos EC. Binocular vision and ocular motility: theory and management of strabismus. Paralytic strabismus. 6th ed. St. Louis: Mosby, 2002; chap. 20.

17) Arici C, Oguz V. The effect of surgical treatment of superior oblique muscle palsy on ocular torsion. J AAPOS 2012;16:21-5.

18) Lee J, Suh SY, Choung HK, Kim SJ. Inferior oblique weakening surgery on ocular torsion in congenital superior oblique palsy. Int J Ophthalmol 2015;8:569-73.

19) Saunders RA. Treatment of superior oblique palsy with superior oblique tendon tuck and inferior oblique muscle myectomy. Ophthalmology 1986;93:1023-7.

\section{$=$ 국문초록 $=$}

\section{단안 상사근마비환자에서 시행한 상사근접치기수술의 효과}

목적: 단안 상사근마비환자에서 첫 수술로 단안 상사근접치기수술 후 경과 관찰시점에 따른 수술 효과의 변화를 알아보고자 하였다. 대상과 방법: 단안의 상사근접치기수술 후 3 개월 이상 경과 관찰한 16 명의 의무기록을 후향적으로 분석하여 술 후 $3,6,12$ 개월, 마지 막 경과 관찰 시 수직사시각, 머리기울임, 상사근기능저하, 하사근기능항진의 호전 여부를 조사하고 안저사진에서 시신경유두 망막중 심오목각을 측정하여 안구회선의 변화를 알아보았다.

결과: 술 후 평균 경과 관찰기간은 $24.9 \pm 21.9$ 개월, 평균 접침양은 $11.4 \pm 4.0 \mathrm{~mm}$ 였다. 제일눈위치의 수직 편위각이 7 프리즘디옵터 이하인 경우는 술 후 3 개월에 $53.9 \%, 6$ 개월에 $50.0 \%, 12$ 개월에 $83.3 \%$, 마지막 경과 관찰 시 $62.5 \%$ 였고, 경과 관찰시점에 따른 유의 한 차이는 없었다 $(p=0.55)$. 머리기울임이 호전된 경우 및 외회선이 감소한 경우는 술 후 $3,6,12$ 개월, 마지막 경과 관찰 시 각각 $66.7 \%, 71.4 \%, 50 \%, 80 \%$ 및 $37.5 \%, 66.7 \%, 75 \%, 80.0 \%$ 였고, 관찰시점에 따른 유의한 차이는 없었다 $(p=0.73, p=0.11)$. 상사근기능저 하 및 하사근기능항진이 호전된 경우는 술 후 $3,6,12$ 개월, 마지막 경과 관찰 시 각각 $100 \%, 77.8 \%, 60 \%, 75 \%$ 및 $100 \%, 88.9 \%$, $85.7 \%, 81.25 \%$ 였다.

결론: 단안 상사근마비환자에서 상사근접치기수술 시행 후 호전된 상태가 수술 후 $3,6,12$ 개월 이후까지 유지되었고, 경과 관찰시점 에 따른 유의한 차이를 보이지 않았다.

〈대한안과학회지 2019;60(10):982-989>

황현지 / Hyun Ji Hwang 건양대학교 의과대학 김안과병원 안과학교실 명곡안연구소 Myung-Gok Eye Research Institute, Department of Ophthalmology, Kim's Eye Hospital, Konyang University College of Medicine 